\title{
Basic and clinical immunology - 3014. Pollen lipid can not stimulate iNKT cells in pollen sensitized patients
}

\author{
Mohammad Fereidouni ${ }^{1 *}$, Shaghayegh Sadat Noorani Hassan Kiadeh ${ }^{1}$, Farahzad Jabbariazad ${ }^{2}$ \\ From 2nd WAO International Scientific Conference (WISC 2012) \\ Hyderabad, India. 6-9 December 2012
}

\section{Background}

Invariant natural killer T (iNKT) cells are a small subset of $\mathrm{T}$ lymphocytes which express a invariant TCR and recognize lipid antigens. They are implicated in a range of immune responses but their role in allergy is controversial. Pollens are the most important trigger of allergic symptoms but their lipid contents may also have a role in allergy through interaction with iNKT cells. The aim of this study was to evaluate the in vitro effect of pollen lipid extract on iNKT cells.

\section{Methods}

PBMCs from 18 pollen-sensitized subjects and 11 healthy controls were isolated and stimulated for 7 days with a mix crude lipid extract of five allergenic pollens prepared by Folch method. Alpha-galactosylceramide and medium were used as positive and negative controls respectively. Proportion of iNKT cells was measured by Flow cytometry using 6B11 and anti-CD3 monoclonal antibodies.

\section{Results}

At day 0, the mean percentage of iNKT cells was $0.42 \pm$ $0.3 \%$ and $0.44 \pm 0.2 \%(\mathrm{P}>0.05)$ for sensitized and control groups respectively. After 7 days culture, iNKT cells from both groups expanded efficiently in response to alphagalactosylceramide and iNKT proportion reaches to $8 \pm$ $5.6 \%$ but lipid extract did not stimulate iNKT proliferation in any groups and the proportion of iNKT cells remained unchanged.

\section{Conclusions}

Based on the results of our study, it seems that pollen lipids are not potent stimulator of iNKT proliferation but further studies need to evaluate the presence and frequency of pollen-specific iNKT cells.

\section{Author details}

${ }^{1}$ Asthma, Allergy \& Immunology Research Center, Birjand University of Medical Sciences, Iran. ${ }^{2}$ Immunology, Mashhad Unviersity of Medical Sciences, Mashhad, Iran.

Published: 23 April 2013

doi:10.1186/1939-4551-6-S1-P190

Cite this article as: Fereidouni et al:: Basic and clinical immunology 3014. Pollen lipid can not stimulate iNKT cells in pollen sensitized patients. World Allergy Organization Journal 2013 6(Suppl 1):P190.
Asthma, Allergy \& Immunology Research Center, Birjand University of Medical Sciences, Iran

Full list of author information is available at the end of the article
Submit your next manuscript to BioMed Central and take full advantage of:

- Convenient online submission

- Thorough peer review

- No space constraints or color figure charges

- Immediate publication on acceptance

- Inclusion in PubMed, CAS, Scopus and Google Scholar

- Research which is freely available for redistribution
C Biomed Central

\section{Biomed Central}

